\title{
Erratum to: 'Mapping the genomic architecture of adaptive traits with interspecific introgressive origin: a coalescent-based approach'
}

Hussein A. Hejase and Kevin J. Liu*

Unfortunately, the original version of this article [1] contained an error. The figures was included incorrectly. The correct figures and their captions can be found below:

Published online: 18 April 2016

\section{Reference}

1. Hejase HA, Liu KJ. Mapping the genomic architecture of adaptive traits with interspecific introgressive origin: a coalescent-based approach. BMC Genomics. 2016;17 Suppl 1:8.

* Correspondence: kjl@msu.edu

Department of Computer Science and Engineering, Michigan State

University, 428 S. Shaw Lane, 48824 East Lansing, Ml, USA
Submit your next manuscript to BioMed Central and we will help you at every step:

- We accept pre-submission inquiries

- Our selector tool helps you to find the most relevant journal

- We provide round the clock customer support

- Convenient online submission

- Thorough peer review

- Inclusion in PubMed and all major indexing services

- Maximum visibility for your research

Submit your manuscript at

www.biomedcentral.com/submit 

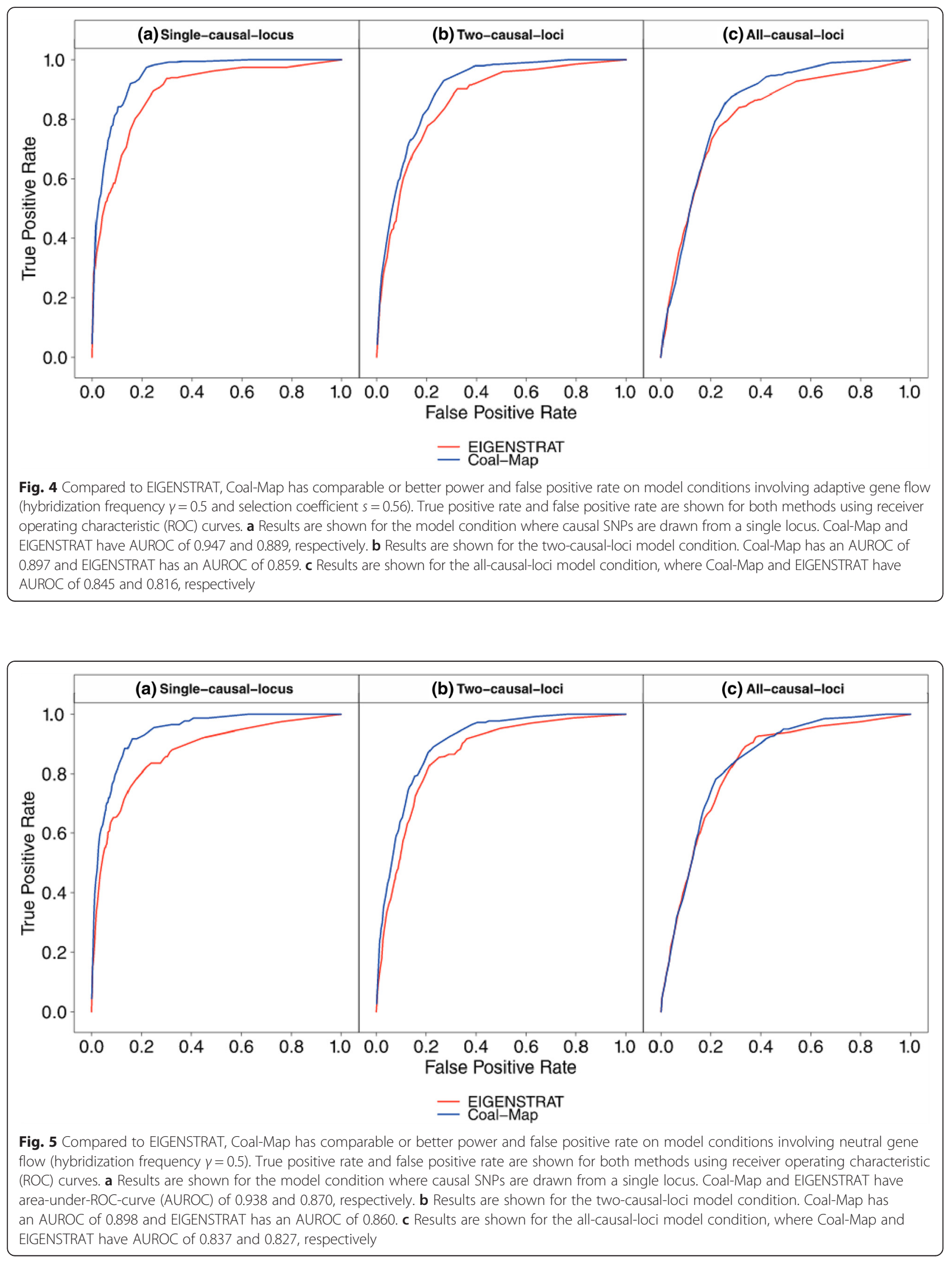


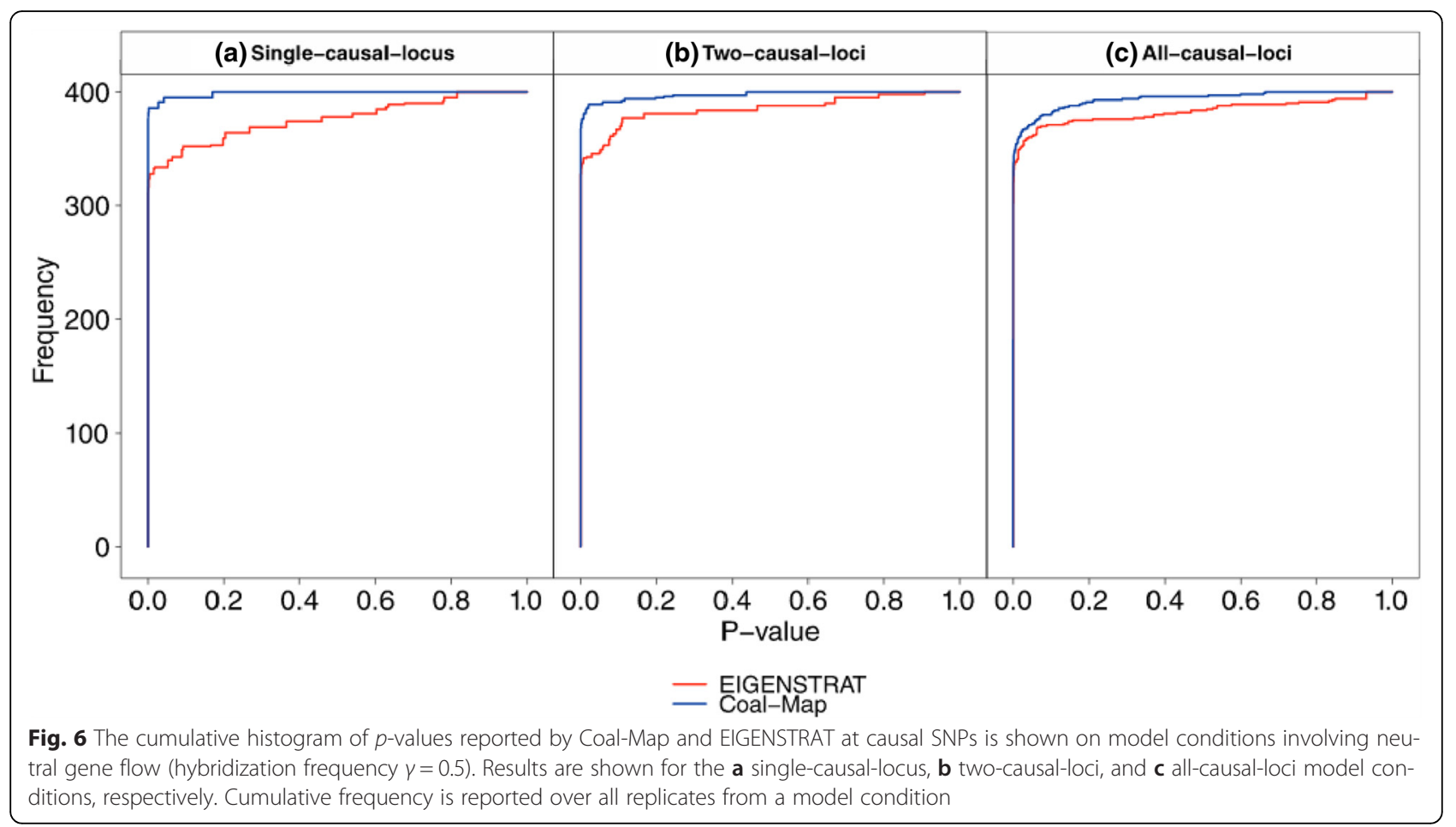

